\title{
Business incubation and the network resources of start-ups
}

\author{
Inger Beate Pettersen ${ }^{1}$, Jarle Aarstad ${ }^{1 *}$, Øystein Stavø Høvig ${ }^{1}$ and Anita Ellen Tobiassen ${ }^{2}$
}

\author{
* Correspondence: \\ jarle.aarstad@hib.no \\ ${ }^{1}$ Bergen University College, PO Box \\ 7030, NO-5020 Bergen, Norway \\ Full list of author information is \\ available at the end of the article
}

\begin{abstract}
The focus in this paper is to study whether business incubation can provide entrepreneurial start-ups with critical network resources. We make a distinction between incubator-provided network resources and start-ups' "own" external network resources that are unrelated to the incubator context. Although there has been an increasing number of studies examining incubated entrepreneurs' network resources, to our knowledge, this is the first study that explicitly compares incubator-provided network resources and start-ups' own external network resources. Analyzing the results from qualitative interviews with start-up tenants at a technology incubator in Bergen, Norway, we find that network resources acquired by the start-ups' own efforts (rather than network resources facilitated by an incubator) were most critical in all phases of enterprise development. They played a crucial role in terms of idiosyncratic (non-generic) knowledge generation as drivers of innovation, catalysts for financial contributors, and as a means to organizational reputation and market access. Nevertheless, internal networking with other incubator firms and external network resources facilitated by the incubator were also helpful and complementary, but they were more generic in nature and provided limited idiosyncratic resources. We also found that incubator network resources tend to have traits similar to those of identity-based network resources because they are not mainly governed by economic interests, but at the same time, they are not path-dependent. Inter-tenant network resources, therefore, can have nonbinding weak-ties properties and provide non-redundant information.
\end{abstract}

Keywords: Start-ups, Network resources, Business incubation, Entrepreneurship

\section{Background}

The focus in this paper is to study whether business incubation can provide entrepreneurial start-ups with critical network resources. A business incubator is defined as a more or less formalized entity with an infrastructure intended to nurture incubated start-ups with critical resources in the pursuit of survival and growth (partly derived from Allen and Rahman 1985). Business incubation can provide the start-ups with resources such as office space, counseling, and other basic services, but their purpose is also to stimulate internal networking and exchange of knowledge between entrepreneurial start-up firms (Hansen et al. 2000; Hughes et al. 2007; Sá and Lee 2012; Kitagawa and Robertson 2012). Furthermore, business incubators should help tenants to build networks with external companies, organizations, and other individuals (Hansen et al. 2000). All in all, one can argue that business incubators may foster network resources, which we define

\section{黛 Springer}

(c) 2016 Pettersen et al. Open Access This article is distributed under the terms of the Creative Commons Attribution 4.0 International License (http://creativecommons.org/licenses/by/4.0/), which permits unrestricted use, distribution, and reproduction in any medium, provided you give appropriate credit to the original author(s) and the source, provide a link to the Creative Commons license, and indicate if changes were made. 
as a firm's access to information, knowledge, reputation, and input factors from a variety of sources such as customers, suppliers, competitors, R\&D institutions, and governmental bodies (partly derived from Spithoven and Teirlinck 2015). The importance of entrepreneurial start-ups' network resources is clearly recognized in the scholarly literature (Hite and Hesterly 2001; Coviello 2006; Pettersen and Tobiassen 2012; Aarstad et al. 2010). Entrepreneurs can use network resources to generate or test ideas, develop new technology, identify market opportunities (Chen and Wang 2008; Sullivan and Marvel 2011), obtain access to financial funding, and gain legitimacy (Pettersen and Tobiassen 2012), to mention a few benefits.

To assess the potential benefits of business incubation, it is therefore critical to study network resources provided by incubators, which include both internal networks among tenants and external networks facilitated by the incubator. Yet to fully comprehend the genuine potential role of business incubation, it is also essential for investigators to compare start-ups' external networks that go beyond the incubator milieu and stem from the path-dependent trajectory of their own efforts and initiatives. In this paper, we therefore make a distinction between (1) incubator-provided network resources (internal and external) and (2) start-ups' "own” external network resources (which are unrelated to the incubator context). Accordingly, we emphasize a variety of factors that are expected to ensure critical network resources to leverage the start-ups' products and services and to enhance long-term growth.

The outline of the paper is as follows: First, we elaborate the concept of entrepreneurial start-ups' network resources, and next, we review studies that have examined incubated entrepreneurial start-ups' network resources. In the following section, we analyze and present the results from qualitative interviews with start-up tenants at a technology incubator in Bergen, the second largest city in Norway and located on the west coast. In the final section, we discuss our empirical findings in light of the existing research literature, address the study's limitations, and suggest avenues for future research.

All in all, we argue that our contribution provides a nuanced picture of entrepreneurial start-ups' network resources residing within and beyond an incubator. Although there has been an increasing number of studies examining incubated entrepreneurs' network resources, to our knowledge, this is the first study that explicitly compares incubator-provided (internal and external) network resources and start-ups' own external network resources. We therefore argue that our study fills an important gap in the research literature on entrepreneurial start-ups in incubation.

\section{Literature review}

\section{Start-ups' network resources}

A network encompasses a set of relationships with various agents or organizations (Walter et al. 2006; Lechner and Dowling 2003). Each of these can provide a focal firm with critical resources. The capability to acquire network resources is critical for entrepreneurial firms (Lechner et al. 2006). Walter et al. (2006) define firm capabilities such as the ability to initiate, maintain, and utilize relationships with various external partners. According to Walter et al. (2006), relationships are also an important means of learning about customers' needs, so that the firm can develop marketable offerings. They found 
that the performance of university spinoffs was positively influenced by their network capability. Mort and Weerawardena (2006) found that networking capability facilitates the development of knowledge-intensive products and allows firms to identify and exploit performance opportunities in international markets.

Building networks shortens and accelerates firms' learning processes (Knight and Cavusgil 1996; Zahra 2005). This is particularly vital for start-ups in their pursuit of development and growth (Schutjens and Stam 2003; Sharma and Blomstermo 2003). Their networks are therefore likely to change over time. According to Hite and Hesterly (2001), identity-based networks, in which the social identity of the ties matters more than the economic functions, are most important in the early stages of growth. However, over time, calculative networks, in which purpose and functions are more important than the identity of the ties, become essential (Hite and Hesterly 2001). This dynamic network evolution is seen as reflecting start-ups' need for resources and the availability of and access to network resources in the various stages of firm development. Thus, in the early growth stage, start-ups basically rely on identity-based networks that are path-dependent because preexisting relationships make them easy to access. Path-dependent networks can provide critical resources but are more restricted, smaller, and less diverse than calculative networks (Hite and Hesterly 2001). At a later stage, when the firm has acquired some reputation and legitimacy, it is willing and able to manage its network intentionally and move beyond the path-dependent core networks. This shift is critical because calculative networks can generally provide greater and more diverse resources and are less redundant than identity-based networks (Hite and Hesterly 2001).

Generally, it is vital for firms to balance path-dependent networks and calculative networks and to emphasize calculative networks at later stages. Start-ups' network resources may furthermore be heterogeneous or multiplex, fostering reputation and market access, the sharing of knowledge, innovation, and technology transfer, and access to financial investors (Lechner and Dowling 2003; Pettersen and Tobiassen 2012). Zheng et al. (2010) argue that the more heterogeneous the networks are, the more diverse information and other resources the start-ups can acquire. Lechner et al. (2006) show that having different types of networks is more important for firm development than network size. Studies have also demonstrated that network heterogeneity helps high-tech start-ups to grow and prosper (Baum et al. 2000; Powell et al. 1996), and Zhao and Aram (1995) have shown that network breadth (and strength) was associated with start-up growth.

\section{Business incubation and network resources}

The literature cited so far primarily emphasizes entrepreneurial networks and network resources in general but does not consider that numerous entrepreneurs are incubated and may hence also profit from incubator-provided network resources. Consequently, it is critical for scholarly research to study both networks that are related to start-ups' incubation and "private" external networks that extend beyond the incubator. In the following review, we therefore pay particular attention to studies related to incubation and incubator network resources.

Cooper et al. (2012, p. 433) note that "[b]usiness incubators strive to develop robust business and social networks to bring value to their resident companies in the form of 
intellectual and material resources." Sá and Lee (2012, p. 243) state that "[o]ne of the central features of incubators is the provision of networking opportunities for tenants to establish collaborative relationships with other organizations." In line with this reasoning, Hansen et al. (2000, p. 75) note that "[m] ost business incubators provide office space, funding, and basic services. The better ones also offer an extensive network of powerful business connections, enabling fledging start-ups to beat their competitors to market."

Although Hansen and colleagues found that only $26 \%$ of the incubator executives interviewed perceived that the incubator in fact provides organized networking, the above statements indicate a consensus in the scholarly literature that the leveraging of network resources should be a crucial mission for business incubators. However, in line with the findings of Hansen et al., the following literature review indicates that the empirical findings are somewhat mixed in this regard.

A recent Finnish study has emphasized the crucial role of multifaceted relations between incubator firms and how they can develop through different processes (Pellinen 2014). In another study in Denmark, Bøllingtoft and Ulhøi (2005) investigated various facets of networking between incubator tenants, and their fieldwork revealed that mutual trust is more important than formal contracts. Tenants do not cooperate "on command;" many of the relationships are multiplex (e.g., friendship and business relations), and joint activities appear to be formative for social ties. Physical proximity is a catalyst for relationship formation (Bøllingtoft 2012; Bøllingtoft and Ulhøi 2005). Similar findings were reported by Cooper et al. (2012) in their investigation of motivations and obstacles to networking in a university incubator. Cooper and colleagues further reported that "primary obstacles residents face... in networking... include lack of ongoing information about other residents, and lack of trust related to keeping information about innovations and funding sources secure" (p. 433).

Chan and Lau (2005) evaluated a university technology business incubator program in Hong Kong; their multiple case study of six incubators revealed that only one appeared to have extensive relationships and knowledge sharing between the incubator firms. A study by Schwartz and Hornych (2008) in Germany examined whether industrial sector specialization incubation would foster internal networking among incubator tenants, but the authors uncovered deficiencies in this regard. A follow-up study did not show that incubator specialization increased internal networking (Schwartz and Hornych 2010). According to Battisti and McAdam (2012), graduate entrepreneurs in incubation face challenges with reference to relational and cognitive dimensions of social capital, which may partly explain Schwartz and Hornych's findings.

A Taiwanese survey indicated that incubator tenants' proactive use of incubator social capital is positively associated with technological capability, managerial competence, and incubation satisfaction (Fang et al. 2010). Recently, a Canadian study by Sá and Lee (2012) reported that networks with crucial stakeholders were created in a major technology incubator (e.g., accounting firms, government agencies, venture capital firms, and research institutes). Some respondents reported that "the social milieu of incubators may be a source of networking opportunities that can translate into business opportunities" (p. 248); thus, it appears that incubator facilities can provide access to credibility and an extended network for the tenants. Nevertheless, the same study concluded that it "seemed almost impractical for the incubator to fully address each of the tenant's networking needs according to their industry and business plans" (p. 251). 
Tötterman and Sten (2005) evaluated three non-profit business incubators in Finland, reporting that "tenants generally experienced that the incubator can, at least to some extent, help them find access to appropriate business networks" (p. 502). "However, each tenant is an individual [firm], and incubators seem to find it hard to systematically tailor-make their services to serve effectively each individual tenant" (p. 503). In a similar vein, a UK-based survey of incubator tenants reported that "incubators often generalize their network support without considering that firms may develop different networks based on their needs" (Soetanto and Jack 2011, p. 127). A follow-up study concluded that "network support for incubator firms can be improved... [and] not all incubator firms have the same needs" (Soetanto and Jack 2013, p. 432). Tötterman and Sten's (2005) contribution from Finland also reported that relationships between tenants were not particularly sophisticated: "In practice, the existing relationships are mainly basic information exchange, often related to daily issues" (p. 502).

McAdam and McAdam (2006, p. 87) concluded in a study from Ireland that the "incubator environment enhances the development of social networks that act to support the new entrepreneur during the vital stages of firm foundation. Furthermore, the networks have a key role in facilitating the design and implementation of firm growth strategies." In another study from Ireland, $79 \%$ of the respondents reported that incubation provides increased and productive network with peers, but they rank such networks to be of low importance (Stephens and Onofrei 2012).

Taken together, the reviewed studies generally indicate that a crucial mission of business incubators is to enable the tenants to leverage network resources internally and with external agents. However, a number of the studies have reported that these activities have proven challenging. Inter-tenant networking is limited and business incubators' mission to foster external network resources is also limited and not particularly adapted "to serve effectively each individual tenant" (Tötterman and Sten 2005, p. 503). It thus appears that network resources shaped through network incubation also tend to be generic in nature. In addition, it is interesting to note that incubation studies are practically silent on comparing the value and characteristics of the path-dependent trajectory of the tenants' "private" networks established prior to incubation and in parallel with incubation. Sá and Lee (2012, p. 248) addressed this issue when referring to incubator start-ups, claiming that "most of their strategic relations were established before locating at MaRS [the incubator] or through their own effort," but we lack systematic knowledge of how incubator tenants may combine incubator network resources with "private" external network resources.

No start-up is conceived in a vacuum, and business ideas are generally initiated prior to incubation. To comprehend fully the nature of incubated network resources, it is accordingly crucial to emphasize how start-ups potentially combine "private" external network resources with incubator-provided internal and external network resources. Because most start-ups not only need generic resources but also depend on specific or idiosyncratic resources for their particular business, it is reasonable to assume that "private" network resources will play a relatively crucial role for incubated tenants; we will address and examine this issue further in the empirical section.

\section{Results}

This section analyzes the data provided from the 10 incubator firms. First, we describe the external networks of the start-ups that go beyond the incubator and stem from the 
tenants' "private" path-dependent trajectory of personal or professional relations. Then, we explain the internal networking within the incubator; finally, we focus on extended network resources facilitated by the incubator management. In the analyses, we emphasize the general experience of the start-ups, and we attempt to reveal their network opportunities both within and beyond the incubator.

\section{Incubator firms' "private" external network resources}

The majority of the entrepreneurs had acquired diverse network resources through education or work experience, which proved valuable for their ventures in their critical start-up phase (i.e., identity-based networks, cf. Hite and Hesterly 2001). Four of the firms in the emergence phase, and one early growth firm, had entrepreneurial teams composed of people with whom they had preexisting relations, such as friends or acquaintances from previous work or study. One informant stated that the firm's present network was mostly composed of "those people we knew before locating at the incubator."

Most start-ups needed pilot customers, which they had to seek proactively beyond their previously established networks (i.e., calculative based networks, cf. Hite and Hesterly 2001). Early growth entrepreneurs in particular had this proactive attitude toward networking. Pilot customers were especially crucial to provide feedback on products and technology and to define the potential market and user preferences. Technology development is costly and time-consuming; hence, it is critical to identify customer needs early. With some exceptions, the majority of the venture ideas were technology driven and not particularly based on user needs. Research-based technologies and advanced technology platforms in particular were far from being specific commercial products. Some pilot customers were financial contributors to research projects and partly financed the firms' technology development by licensing and buying prototypes and through what has been labelled industrial R\&D contracts (facilitated by Innovation Norway, a governmental body).

The pilot customers therefore contributed multiple and multiplex resources to the development and growth of the start-ups. Large and well-known pilot customers additionally functioned as reputational agents enhancing the start-ups' legitimacy. The incubator firms expected (or wished) that pilot customers would become future loyal customers; yet because of product and technology uncertainties, the pilot customers would not often fully commit themselves to the projects before they were completed.

Access to financial resources was critical for most of the firms in the technology development phase. In addition to pilot customers, most entrepreneurs obtained grants from Innovation Norway. Generally, it was difficult to obtain financial resources from private investors, because early phase ventures were typically perceived as high-risk projects. Nevertheless, four of the start-ups had succeeded in attracting bank or industry investors, albeit for a limited period, while others were in the process of searching for investors. However, a number of the start-ups were skeptical of investors who anticipated a major influence over the venture's future course. Some therefore preferred to maintain ownership control of their venture at this early stage as they perceived that "selling out" would also mean "losing control." Research-based technology projects were often funded by research programs, while other complex technology projects without a research base 
typically struggled to obtain financial resources. Hence, the start-ups relied on various sources to finance the ventures' early development and growth, such as public organizations (e.g., grants from Innovation Norway), the Research Council of Norway, regional banks, and other industrial investors.

The majority of the firms essentially developed the technology in-house with internal technology knowledge and resources. In addition, some firms outsourced specific programming and developing tasks to external organizations and consultants, in Norway and abroad. These relationships can be labelled knowledge, innovation, and technology networks (Lechner and Dowling 2003; Pettersen and Tobiassen 2012). As the technology and product are critical assets in the entrepreneurial venture, they preferred to keep fundamental technology development in-house to avoid the risk of copying. Two firms with research-based technologies needed external R\&D partners to develop them. External researchers contributed to the development of some of the ventures' technology. Hence, external R\&D partners functioned as knowledge, innovation, and technology networks for these firms. Overall, research-based entrepreneurial firms had extensive R\&D networks that were critical to leveraging the enterprise.

For the majority of the firms in the emergence phase, their "private" network had a high proportion of ties where some form of identity-based personal or social relationship motivated their actions. This goes for entrepreneurial team formation, acquiring pilot customers, and technology development. For the firms in the early growth phase, their network was more multiplex, mostly with a mix of identity and calculative ties. As firms in the early growth phase require more extensive and a wider range of resources than were first needed, there is a tendency to move from identity to calculative ties.

To summarize, the "private" external network resources were mainly acquired through the start-ups' own efforts, rather than facilitated by the incubator. The start-ups' "private" external networks can be described as critical resources that enabled the firms to develop their technology and venture further. We label these network resources "idiosyncratic" because they satisfied the firms' specific and individual needs.

\section{Network resources developed internally among start-ups in the incubator}

Few start-ups found collaboration partners within the incubator that could provide critical network resources. (The only exceptions were the two firms originating in "start-up communities" that are now collaborating to leverage a spinoff. We will discuss them below.) Nevertheless, the start-ups communicated with other incubator firms and especially emphasized the sharing of entrepreneurial experience. Most incubator firms exchanged knowledge and experiences related to the various phases in developing a business. In fact, they found it valuable to share such experiences, because they could learn from each other and provide mutual moral support. Even though most firms had different technologies targeting different markets, they had to undergo the same critical phases: technology development, production, and sales and marketing. As one informant put it: "Even though we have different products and technologies, and we target a different market from other incubated firms, we evolve through the same stages of emergence and growth. The challenges that we face and the experiences we gain are similar and transferable." Another informant emphasized the generic resources that the different firms were able to share: "[The sharing of] accounting and auditing tips, tax 
reduction schemes and those things. Everyone will encounter these, and we should be able to share experiences and discuss them openly without secrecy." Inter-tenant networking was thus mostly related to general or generic challenges that most start-ups face in the early growth stage: managing technology transitions, preparing for investors, taxation and auditing, and negotiating with customers and other critical stakeholders.

The firms shared these experiences openly without secrecy, because they had a more generic character. Most start-ups recognized that they differed widely with respect to products and markets and it was difficult to find partners with matching knowledge at the incubator. Furthermore, some start-ups were reluctant to share business secrets and their "own" network resources because of potential rivalry. This was especially so for investor resources, which are scarce in Bergen. As one tenant put it: "All start-ups compete for the same money; hence, there is no exchange of information in this regard."

Another reason for the limited inter-tenant information sharing was the lack of knowledge about other tenants. Without necessary knowledge, it is difficult to identify potential synergies and areas for collaboration. All incubator firms had some contact with other tenants, but they lacked the comprehensive and detailed knowledge about the other firms required to exploit this potential fully.

We have briefly mentioned that two incubator start-ups are now collaborating to leverage a spinoff. Anecdotally, this can be described as "the exception that proves the rule," but it is worth noting that these are the only entrepreneurs that have emerged from what we have labelled "start-up communities." This may indicate that such startups have a greater proclivity to be flexible and open-minded in terms of generating novel ideas. It also indicates that they are willing to share critical resources with others showing similar attitudes to their own.

Although internal networking was rarely related to critical network resources, the sharing of the entrepreneurial experience was considered valuable for the firms in further development of the business and because of the social and moral support it provided. Since the start-up process can be lonely, with numerous barriers to overcome, interacting with other entrepreneurs facing similar challenges can lessen this burden. It was important for the start-ups to reside in the incubator and be part of an entrepreneurial milieu for these reasons. We can refer to these internal network resources, stemming from within the incubator milieu, as mostly generic in nature.

\section{External network resources provided by the incubator}

The incubator management manages an extended network encompassing R\&D institutions, public bodies, law firms, regional network organizations, investor groups, a technology transfer office, and diverse industry contacts and networks. Hence, the incubator management could provide contacts and information related to legal counseling and accounting, business development programs, funding opportunities, and other issues that were valuable for the firms. The technology transfer office organized intensive innovation programs for entrepreneurs developing business models and market plans, in which several of the incubator firms participated. These programs were adapted to certain industries or classes of products, and they complemented the services and business counseling directly provided by the incubator. They were reported to be highly valued by the start-ups that participated in them. 
Another organization in the extended incubator network-organized events that connected start-ups with potential investors. Some of the start-ups participated in these events, but they reported marginal results, because of the lack of opportunities for matchmaking or forming enduring relationships with potential investors. On the other hand, given that our data stem from "the eye of the beholder," i.e., business start-ups, it could very well be that potential investors would have a different story to tell, such as considering very few of the participating ventures to be worthy candidates for high-risk investments.

Taken together, the incubator and its extended network contributed business development programs to the start-ups and provided important information, contacts, and networks on legal aspects and funding opportunities, among other benefits. In line with the inter-tenant network resources, these advisory and strategic network resources can be labelled generic in nature.

\section{Synthesis of the findings}

The incubator firms mainly relied on "private" external networks beyond the incubator to acquire critical resources. These were identity-based and path-dependent networks established prior to incubation or more recent calculative networks that they had actively sought. Hence, the incubator firms took responsibility for acquiring networks and did not rely solely on the incubator for critical network resources. This implies that the incubator management, and the internal networks between incubator firms and the incubator's extended network, to a modest extent provided the firms with critical (idiosyncratic) external network resources but instead provided the start-ups with strategic and advisory network resources that are more generic in nature. Hence, the research findings show that practically all tenants had abundant external "private" network resources that can be described as idiosyncratic (non-generic) in nature. All of the tenants had their own story to tell about the development of these network resources, both before and after incubation. These external network resources were most critical for start-ups in all phases of the enterprise development through their provision of R\&D knowledge, access to monetary funding, and market access.

Internal inter-tenant networking in the form of sharing the entrepreneurial experience with other incubator firms was also important, but it was more strongly related to the similar phases that start-ups undergo as they evolve. It also served a social purpose, such as satisfying the need to belong to a wider community. We therefore describe these internal network resources as generic, because they satisfy the more common needs of the firms. In contrast, external "private" network resources can be described as idiosyncratic because they satisfy specific needs of an individual firm and are not easily transferable across firm boundaries (Gibbert 2006; Aarstad 2014). As noted above, the exceptions to these trends were the two incubated software firms that are now in the process of leveraging a spinoff; however, we were unable to identify similar patterns for the eight other firms.

We summarize our major empirical findings in Table 1. The "internal" inter-tenant incubator network and the external network accessed through the incubator management provide limited idiosyncratic resources but fairly abundant generic resources. Most tenants have fairly abundant idiosyncratic external "private" network resources, 
Table 1 Network resources and the incubator's role

\begin{tabular}{lll}
\hline & Network resources & \\
\hline & Idiosyncratic (non-generic) & Generic \\
Internal inter-tenant incubator networks and external networks & Limited & Fairly abundant \\
accessed through incubator management & & \\
External "private" networks not related to the incubator milieu & Fairly abundant & Variable \\
\hline
\end{tabular}

but they report that they are in need of generic network resources. In other words, incubation has played a crucial role in allowing at least some of the firms to gain access to generic network resources, enabling them to learn about financial opportunities, legal issues, and so on. The tenants have gained this knowledge through inter-tenant networking and through professional assistance provided by the incubator management. However, in terms of idiosyncratic network resources, the incubator seemed to play a limited role for most firms. In other words, there appear to be few synergy effects in terms of genuine spill-over effects and technological transfer between the firms. In general, tenants report that this results from firm heterogeneity and to a lesser degree from secrecy.

\section{Discussion}

As described above, the majority of networks that ensured critical resources in the different phases of the life cycle of start-ups were external "private" networks that were not related to the incubator milieu. In addition, the start-ups actively sought new network resources (calculative networks) and used their own (path-dependent and identity-based) networks acquired before incubation. The entrepreneurs only to a limited degree relied on the incubator and its extended network to acquire the critical network resources. Several factors may explain these findings.

One possible reason is that the venture idea typically had its origins in previous work or R\&D experience before the firms entered the incubator. The majority of the startups had extensive networks to draw on when establishing the venture, and searched their preexisting, path-dependent networks, which led to a path-dependent form of evolution that according to Hite and Hesterly (2001) is quite common for entrepreneurs. At the early stage of establishing an entrepreneurial team, the start-ups mainly drew upon identity-based networks, such as fellow students, researchers, or job colleagues. In the technology development phase, the firms relied on a mix of networks, both identity-based and more calculative and intentionally managed networks. During the late technology development phase, they needed other resources that were not available in previous networks, and they proactively and calculatedly searched for pilot customers and investors. Hence, the start-ups were able to shift to more calculative networks and to balance identity-based and calculative networks, in the manner emphasized by Hite and Hesterly (2001). Other studies of incubators and networking (e.g., Sá and Lee 2012) support our findings, noting that the start-ups "claimed that most of their strategic relations were established before locating at MaRS [the incubator] or through their own effort" (p. 248).

Thus, our findings show that start-ups mainly relied on external "private" networks to access critical resources. It may be evident that an incubator milieu would not provide financial and market resources, because such actors (investors and customers) do 
not normally reside in incubators. On the other hand, we would expect that the incubator milieu could foster knowledge, innovation, and technology networks. Some of the tenants had in fact used other tenants to assist them in specific development tasks, but these contributions were not perceived as critical for the firms. Except for the case that contributed to an incubator spinoff (noted above), tenants did not engage in extensive knowledge, innovation, and technology-related networking with other tenants.

Even though some start-ups had certain commonalities with respect to technology or market segments, they were nevertheless highly specialized. Tenants therefore experienced difficulties in finding potential collaboration partners within the incubator. Thus, because the firms were heterogeneous and highly specialized, it was difficult for the incubator management to facilitate relevant internal networks. Hence, the firms needed a larger pool of firms and contacts (beyond the incubator) to search for relevant networks and network resources. Consistent with our findings, Sá and Lee (2012) concluded that start-ups' networking strategies were only to some extent fostered by networks promoted by an incubator. Tötterman and Sten (2005) found that an excessively diverse company mix among the tenants limited potential synergies and hence reduced collaboration opportunities. They further concluded that relationships among incubator tenants were not as sophisticated as previous research has suggested: "it seems to be relatively rare that an incubator network is able to systematically provide tenants with resources that would otherwise be unreachable for them" (p. 503).

Rivalry and secrecy among the tenants were other explanations for the scarcity of networking among the start-ups in our study. Tenants differed somewhat with respect to sharing knowledge and network resources. Some tenants were open and willing to share and collaborate with other tenants, while others were reluctant. Some incubator firms feared that engaging in collaboration in fundamental technology and other firm assets would reveal essential business secrets and put the competitive advantage of the firm at risk. With respect to their own networks related to parties such as customers and investors, some emphasized the rivalry dimension and the risk of losing out in competition with others. Previous studies on incubators also refer to these issues. Sá and Lee (2012) observed conflicts around collaborative aspirations among tenants and obligations to protect their intellectual property. Furthermore, the tenants they studied were concerned about competition because there were overlapping business interests and limited resources, partners, and clients. This is especially the case for shared investor resources, which are considered to be scarce in Bergen. Cooper et al. (2012) found that a lack of trust among tenants and the fear that information would not be treated confidentially were a barrier to collaboration and a sharing culture. Oakey (2007) noted that entrepreneurs were reluctant to discuss their new product ideas with other entrepreneurs for fear that their intellectual property would be copied.

A final explanation for the limited extent of inter-tenant information sharing reported in our study was the lack of knowledge about other tenants. Without the necessary knowledge, it was difficult to identify potential synergies and areas for collaboration. All incubator firms had some contact with other tenants, but they lacked the comprehensive and detailed knowledge about the other firms required to exploit this potential fully. The entrepreneurs recognized that internal networking could be strengthened within the incubator. More informal contact, common seminars where tenants present their projects, and a more developed "sharing" culture could remedy this. The above 
findings have also been identified in previous research (e.g., Cooper et al. 2012; Tötterman and Sten 2005).

\section{Conclusions}

Recently, an increasing number of studies have shown how business incubation can provide start-ups with network resources. Our study adds to this literature in that we have compared incubator-provided network resources, inter-tenant networking, and the tenants' "private" path-dependent trajectory of external network resources that are not related to the incubator milieu. To our knowledge, this is the first study intended to distinguish and systematize incubator firms' network resources according to these dimensions. Therefore, our research builds on prior studies, yet contributes to and advances scholarly research by providing a nuanced picture of network opportunities provided by incubators, and by distinguishing the types and nature of different network resources that reside within and beyond the incubator.

Overall, our data indicate that incubation can provide generic network resources but to a lesser extent offers idiosyncratic (non-generic) network resources. It can therefore be argued that incubator-provided networks can complement, but not substitute, tenants' external "private" networks, which appear to be crucial for access to idiosyncratic resources.

In addition to contributing to the scholarly literature, we argue that our study also has implications for policy makers and incubator managers. First and foremost, incubation in itself appears to be no "quick fix" for tenants to ensure the necessary network resources to develop and grow; nor does it appear that an incubator can serve solely as a catalyst for the provision of critical network resources. Notwithstanding these limitations, an incubator definitely plays a crucial role in that it can provide necessary assistance in terms of generic network resources. Some of the tenants also report that social events can spur inspiration, acquaintance, and a sense of "belonging" ("we are in this together") in pursuit of leveraging their venture. In particular, it appears that physical proximity propels social acquaintances, which is also in line with studies cited above (Bøllingtoft 2012; Cooper et al. 2012).

Furthermore, it is interesting to learn that incubator network resources tend to have traits similar to those of identity-based network resources because they are not mainly governed by economic interests, but at the same time, they are not path-dependent. Inter-tenant network resources, therefore, can have a mix of nonbinding weak-ties (Granovetter 1973) properties that also provide non-redundant information from different perspectives (Burt 1992). These are topics for further investigation in future incubation research.

Future research should finally aim to gain further knowledge about our observation that entrepreneurs emerging from so-called "start-up communities" were able to share idiosyncratic resources, enabling the establishment of a spinoff. We need to know if these findings can be generalized beyond the two cases studied here. This may have implications on recruitment policy and the management of business incubators. To our knowledge, comparisons of different entrepreneurial styles have not been carried out with reference to incubation research.

Data were gathered from only a limited number of firms residing in one incubator. Thus, future researchers should aim to gather data from a larger pool of start-ups 
residing in a variety of incubators. Data were furthermore gathered retrospectively. Longitudinal studies are therefore warranted in future studies, in which the candidate firms are followed through the pre-founding and pre-incubation stages, the incubation stage, and preferably into the post-incubation stages. Comparative studies should also be conducted in which the networking patterns of incubated start-ups are compared longitudinally with non-incubated start-ups.

\section{Methods}

\section{Research context}

Our empirical data stem from archival information and semi-structured interviews with entrepreneurial tenants at a not-for-profit and publicly funded technology incubator in Bergen, Norway. Criteria for acceptance as tenants are that the start-ups in some way are knowledge-intensive and show potential for growth. Occupancy in the incubator is normally limited to 3 years. The incubator provides the tenants with business counseling that strengthens start-ups and helps them focus on the commercialization and market orientation of the venture. Furthermore, the incubator management organizes seminars on relevant topics, such as how to prepare for investors, choice of intellectual property rights strategy, selling, and contracting. The incubator also offers a social and professional environment with other start-ups, office space ("below market" rent), other relevant infrastructure (e.g., Internet), and access to the incubator's extended network. In addition to the general manager, the incubator has two business developers who work part-time, one communication manager (part-time), and one student on internship (part-time).

The incubator collaborates closely with an extended network of organizations supporting and fostering innovation. A number of these organizations are localized in close proximity to the incubator. One of them is a technology transfer office, which is responsible for organizing intensive innovation programs to entrepreneurs to strengthen the commercial focus of the start-ups. One organization connects entrepreneurs with potential investors during specific events. A third provider of external network resources is a seed capital fund that invests in Norwegian technology start-ups at an early stage of their enterprise development. The incubator also collaborates with a wider regional network of organizations and networks supporting innovation, other regional incubators, and regional industry clusters.

\section{Data}

Our data methodology can be described as an embedded case study (Yin 2003) that explores issues occurring in a realistic context and is designed to combine an inductive and deductive approach (Eisenhardt 1989). Before conducting interviews with tenants, we conducted a semi-structured interview with the incubator manager to gain an overview of the incubator and the facilities it provides. We also searched publicly available information about the tenants' financial status and their own presentations on their Internet home pages.

We developed an interview guide in which the questions were grounded in relevant research on entrepreneurs and networks (Hite and Hesterly 2001; Lechner and Dowling 2003; Lechner et al. 2006). Ten interviews with incubator firms were used in the data 
analyses for this study. At the time of data collection, which took place during early 2013, the incubator had 14 tenants. Two tenants were in "post-incubation" and not relevant to our study. Thus, we have interview data from 10 of 12 relevant incubator firms. Each interview lasted for approximately $1.5 \mathrm{~h}$. The interviews were recorded and subsequently transcribed. During the interviews, our specific intent was to scrutinize the tenants' perceptions of network resources leveraged or facilitated by the incubator, as opposed to the path-dependent trajectory of their own "private" network resources.

The data were analyzed with reference to Miles et al. (2014). The analysis began with descriptive coding, process coding, and evaluation coding. We also applied deductive coding based on the initial theoretical framework of the research and inductive coding as the analysis and interpretation of data emerged. Subsequently, we analyzed pattern codes, that is, searching for categories and themes. We also explored eventual causal relationships and explanations in the data and investigated the relationships between individuals and firms. Three of the researchers conducted the interviews, and all researchers contributed to the analyses and interpretation of the data. This research collaboration developed inter-subjectivity and strengthened the validity and reliability of the research and hence reduced potential personal bias and "going native" biases (Miles et al. 2014).

\section{Description of the interviewed tenants}

The majority of the tenants are knowledge- and technology-intensive firms, developing or producing hardware (e.g., oil and chemical spill recovery systems) or software products (e.g., mobile applications or web-based tools). Four firms target the offshore oil and gas sector, which is important in the region. Other firms are anchored in the regional media cluster or position themselves in relation to other service industries (see Table 2).

Three of the firms that target the offshore oil and gas sector deploy research-based technology, and they have relied on research collaboration and research funding to develop it. The founders have acquired research networks through their master's or $\mathrm{PhD}$ studies, but they also have close connections to the industry and potential customers. Five firms are in fields in which the founders have previous experience, while two sprung out of the founders' participation in and relations with what can be labelled a "start-up community" of young entrepreneurs. Five of the incubator firms have relatively young founders, of which four have founders with limited relevant work experience. Most of the other founders have extensive work experience, either in the region or internationally. The start-ups have limited or no prior entrepreneurial experience. Most start-ups consist of entrepreneurial teams of between two and five employees.

All firms are in an early phase of their life cycle. In terms of a stage approach to the evolution of firms (Lewis and Churchill 1983), six of the firms can be classified as being in the emergence phase, where they experience a high degree of uncertainty regarding resources, routines, and product development. Four of the firms are in the early growth phase, where they require both more extensive and a wider range of resources than was first needed, such as technological development resources, pilot customers, investors, and financial funding. We address the issue of network orientation below. 
Table 2 Descriptive summary of the interviewed tenant firms

\begin{tabular}{|c|c|c|c|c|c|c|c|c|}
\hline Firm number (year established) & Product type & Target sector & Origin of venture idea & Founders' age & $\begin{array}{l}\text { Relevant work } \\
\text { experience }\end{array}$ & $\begin{array}{l}\text { Previous entrepreneurial } \\
\text { experience }\end{array}$ & Entrepreneurial stage & Network orientation \\
\hline $1(2007)$ & Software & Oil and gas & R\&D institution & Middle aged & Some & None & Early growth & Calculative \\
\hline $2(2007)$ & Software & Oil and gas & Previous work experience & Middle aged & Limited & None & Early growth & Identity \\
\hline $3(2009)$ & Hardware & Oil and gas & R\&D institution & Young & Limited & None & Early growth & Calculative \\
\hline $4(2011)$ & Hardware & Oil and gas & $R \& D$ institution & Middle aged & Extensive & None & Emergence & Calculative \\
\hline $5(2007)$ & Software & Media & Previous work experience & Middle aged & Extensive & None & Early growth & Calculative \\
\hline $6(2010)$ & Software & Media & Previous work experience & Middle aged & Extensive & Limited & Emergence & Identity \\
\hline 7 (2011) & Software & Restaurant & Start-up community & Young & Limited & None & Emergence & Identity \\
\hline $8(2011)$ & Software & Media & Previous work experience & Young & Limited & None & Emergence & Identity \\
\hline $9(2011)$ & Software & Finance & Previous work experience & Young & Some & None & Emergence & Identity \\
\hline $10(2010)$ & Software & Media & Start-up community & Young & Limited & None & Emergence & Identity \\
\hline
\end{tabular}




\section{Competing interests}

The authors declare that they have no competing interests.

\section{Authors' contributions}

$\varnothing \mathrm{H}, \mathrm{IB}$, and JA designed the study. IB and JA wrote the major part of the paper. $\varnothing \mathrm{H}$ and AT wrote parts of the paper. $\varnothing \mathrm{H}, \mathrm{IB}$, and JA gathered and analyzed data for this paper. $\varnothing \mathrm{H}, \mathrm{IB}$, and JA edited the paper. All authors read and approved the final manuscript.

\section{Author details}

${ }^{1}$ Bergen University College, PO Box 7030, NO-5020 Bergen, Norway. ${ }^{2}$ Oslo and Akershus University College, PO Box 4, 0131 Oslo, Norway.

Received: 20 October 2015 Accepted: 27 January 2016

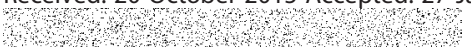

\section{References}

Aarstad, J. (2014). Resource idiosyncrasy, performance, and inter-firm small-world networks. Journal of Strategy and Management, 7(1), 19-29. doi:10.1108/JSMA-03-2013-0018.

Aarstad, J., Haugland, S. A., \& Greve, A. (2010). Performance spillover effects in entrepreneurial networks: assessing a dyadic theory of social capital. Entrepreneurship: Theory and Practice, 34(5), 1003-1020.

Allen, D. N., \& Rahman, S. (1985). Small business incubators: a positive environment for entrepreneurship. Journal of Small Business Management, 23(3), 12-22.

Battisti, M., \& McAdam, M. (2012). Challenges of social capital development in the university science incubator: the case of the graduate entrepreneur. The International Journal of Entrepreneurship and Innovation, 13(4), 261-276. doi:10. 5367/ijei.2012.0091.

Baum, J. A. C., Calabrese, T., \& Silverman, B. S. (2000). Don't go it alone: alliance network composition and startups' performance in Canadian biotechnology. Strategic Management Journal, 21(3), 267-294.

Burt, R. S. (1992). Structural holes: the social structure of competition. Cambridge, MA: Harvard University Press.

Bøllingtoft, A. (2012). The bottom-up business incubator: leverage to networking and cooperation practices in a self-generated, entrepreneurial-enabled environment. Technovation, 32(5), 304-315. doi:10.1016/j.technovation. 2011.11.005.

Bøllingtoft, A., \& Ulhøi, J. P. (2005). The networked business incubator-leveraging entrepreneurial agency? Journal of Business Venturing, 20(2), 265-290.

Chan, K. F., \& Lau, T. (2005). Assessing technology incubator programs in the science park: the good, the bad and the ugly. Technovation, 25(10), 1215-1228.

Chen, M.-H., \& Wang, M.-C. (2008). Social networks and a new venture's innovative capability: the role of trust within entrepreneurial teams. R\&D Management, 38(3), 253-264. doi:10.1111/j.1467-9310.2008.00515.x.

Cooper, C. E., Hamel, S. A., \& Connaughton, S. L. (2012). Motivations and obstacles to networking in a university business incubator. Journal of Technology Transfer, 37(4), 433-453. doi:10.1007/s10961-010-9189-0.

Coviello, N. E. (2006). The network dynamics of international new ventures. Journal of International Business Studies, 37(5), 713-731. doi:10.1057/palgrave.jibs.8400219.

Eisenhardt, K. M. (1989). Building theories from case study research. Academy of Management Review, 14(4), 532-550.

Fang, S. C., Tsai, F. S., \& Lin, J. L. (2010). Leveraging tenant-incubator social capital for organizational learning and performance in incubation programme. [Review]. International Small Business Journal, 28(1), 90-113. doi:10.1177/ 0266242609350853

Gibbert, M. (2006). Generalizing about uniqueness-an essay on an apparent paradox in the resource-based view. Journal of Management Inquiry, 15(2), 124-134. doi:10.1177/1056492606287793.

Granovetter, M. (1973). The strength of weak ties. American Journal of Sociology, 78, 1360-1380.

Hansen, M. T., Chesbrough, H. W., Nohria, N., \& Sull, D. N. (2000). Networked incubators-hothouses of the new economy. Harvard Business Review, 78(5), 74. +

Hite, J. M., \& Hesterly, W. S. (2001). The evolution of firm networks: from emergence to early growth of the firm. Strategic Management Journal, 22(Spring), 275-286.

Hughes, M., Ireland, R. D., \& Morgan, R. E. (2007). Stimulating dynamic value: social capital and business incubation as a pathway to competitive success. Long Range Planning, 40(2), 154-177. doi:10.1016/j.lrp.2007.03.008.

Kitagawa, F., \& Robertson, S. (2012). High-tech entrepreneurial firms in a university-based business incubator: spaces of knowledge, resource heterogeneity and capital formation. The International Journal of Entrepreneurship and Innovation, 13(4), 249-259. doi:10.5367/ijei.2012.0092

Knight, G. A., \& Cavusgil, S. T. (1996). The born global firm: a challenge to internationalization theory. In S. T. Cavusgil \& T. K. Madsen (Eds.), Export Internationalization Research - Enrichment and Challenges (Vol. 8, pp. 11-26). New York, NY: JAI Press.

Lechner, C., \& Dowling, M. (2003). Firm networks: external relationships as sources for the growth and competitiveness of entrepreneurial firms. Entrepreneurship and Regional Development, 15(1), 1-26. doi:10.1080/08985620210159220.

Lechner, C., Dowling, M., \& Welpe, I. (2006). Firm networks and firm development: the role of the relational mix. Journal of Business Venturing, 21(4), 514-540. doi:10.1016/j.jbusvent.2005.02.004.

Lewis, V. L., \& Churchill, N. C. (1983). The five stages of small business growth. Harvard Business Review, 61(3), 30-50

McAdam, M., \& McAdam, R. (2006). The networked incubator: the role and operation of entrepreneurial networking with the university science park incubator (USI). The International Journal of Entrepreneurship and Innovation, 7(2), 87-97. doi:10.5367/000000006776928663.

Miles, M. B., Huberman, A. M., \& Saldaña, J. (2014). Qualitative data analysis: a methods sourcebook (3rd ed.). CA: Sage.

Mort, G. S., \& Weerawardena, J. (2006). Networking capability and international entrepreneurship: how networks function in Australian born global firms. International Marketing Review, 23(5), 549-572. 
Oakey, R. (2007). Clustering and the R\&D management of high-technology small firms: in theory and practice. $R \& D$ Management, 37(3), 237-248. doi:10.1111/j.1467-9310.2007.00472.x.

Pellinen, K. (2014). The interplay of entrepreneurial and network activities in the entrepreneurial process: a relational analysis. The International Journal of Entrepreneurship and Innovation, 15(1), 17-28. doi:10.5367/ijei.2014.0137.

Pettersen, I. B., \& Tobiassen, A. E. (2012). Are born globals really born globals? The case of academic spin-offs with long development periods. Journal of International Entrepreneurship, 10(2), 117-141. doi:10.1007/s10843-012-0086-5.

Powell, W. W., Koput, K. W., \& Smith-Doerr, L. (1996). Interorganizational collaboration and the locus of innovation: networks of learning in biotechnology. Administrative Science Quarterly, 41(1), 116-145.

Sá, C., \& Lee, H. (2012). Science, business, and innovation: understanding networks in technology-based incubators. R\&D Management, 42(3), 243-253. doi:10.1111/j.1467-9310.2012.00681.x

Schutjens, V., \& Stam, E. (2003). The evolution and nature of young firm networks: a longitudinal perspective. Small Business Economics, 21(2), 115-134. doi:10.1023/A:1025093611364.

Schwartz, M., \& Hornych, C. (2008). Specialization as strategy for business incubators: an assessment of the Central German Multimedia Center. Technovation, 28(7), 436-449. doi:10.1016/j.technovation.2008.02.003.

Schwartz, M., \& Hornych, C. (2010). Cooperation patterns of incubator firms and the impact of incubator specialization: empirical evidence from Germany. Technovation, 30(9-10), 485-495. doi:10.1016/j.technovation.2010.05.001.

Sharma, D. D., \& Blomstermo, A. (2003). The internationalization process of Born Globals: a network view. International Business Review, 12(6), 739-753.

Soetanto, D. P., \& Jack, S. (2013). Business incubators and the networks of technology-based firms. The Journal of Technology Transfer, 38(4), 432-453. doi:10.1007/s10961-011-9237-4.

Soetanto, D. P., \& Jack, S. L. (2011). Networks and networking activities of innovative firms in incubators: an exploratory study. The International Journal of Entrepreneurship and Innovation, 12(2), 127-136. doi:10.5367/ijei.2011.0027.

Spithoven, A., \& Teirlinck, P. (2015). Internal capabilities, network resources and appropriation mechanisms as determinants of R\&D outsourcing. Research Policy, 44(3), 711-725. doi:10.1016/j.respol.2014.10.013.

Stephens, S., \& Onofrei, G. (2012). Measuring business incubation outcomes: an Irish case study. The International Journal of Entrepreneurship and Innovation, 13(4), 277-285. doi:10.5367/ijei.2012.0094.

Sullivan, D. M., \& Marvel, M. R. (2011). Knowledge acquisition, network reliance, and early-stage technology venture outcomes. Journal of Management Studies, 48(6), 1169-1193. doi:10.1111/j.1467-6486.2010.00998.x.

Tötterman, H., \& Sten, J. (2005). Start-ups: business incubation and social capital. International Small Business Journal, 23(5), 487-511. doi:10.1177/0266242605055909.

Walter, A., Auer, M., \& Ritter, T. (2006). The impact of network capabilities and entrepreneurial orientation on university spin-off performance. Journal of Business Venturing, 21(4), 541-567. doi:10.1016/j.jbusvent.2005.02.005.

Yin, R. K. (2003). Case study research (3rd ed.). Thousand Oaks, CA: Sage.

Zahra, S. A. (2005). Entrepreneurial risk taking in family firms. Family Business Review, 18(1), 23-40. doi:10.1111/j. 1741-6248.2005.00028.x

Zhao, L., \& Aram, J. D. (1995). Networking and growth of young technology-intensive ventures in China. Journal of Business Venturing, 10(5), 349-370. doi:10.1016/0883-9026(95)00039-B.

Zheng, Y. F., Liu, J., \& George, G. (2010). The dynamic impact of innovative capability and inter-firm network on firm valuation: a longitudinal study of biotechnology start-ups. Journal of Business Venturing, 25(6), 593-609.

\section{Submit your manuscript to a SpringerOpen ${ }^{\circ}$} journal and benefit from:

- Convenient online submission

- Rigorous peer review

- Immediate publication on acceptance

- Open access: articles freely available online

- High visibility within the field

- Retaining the copyright to your article

Submit your next manuscript at $>$ springeropen.com 